\title{
RECENZJE
}

\author{
MONIKA SZYMAŃSKA*
}

INSTYTUT JĘZYKA POLSKIEGO POLSKIEJ AKADEMII NAUK, KRAKÓW

\section{Marek Łaziński, Wykłady o aspekcie polskiego czasownika}

WYDAWNICTWA UNIWERSYTETU WARSZAWSKIEGO, WARSZAWA 2020, S. 315

doi: http://dx.doi.org/10.31286/JP.101.4.10

Monografia Marka Łazińskiego prezentuje ogólną charakterystykę aspektu jako kategorii gramatycznej. Jest to charakterystyka wielowymiarowa - przedstawiająca między innymi formalne wyznaczniki aspektu, istotę opozycji aspektowej obecną w warstwie semantycznej oraz funkcje tekstowe aspektu - a przy tym ukierunkowana na ukazanie tej kategorii jako pod wieloma względami szczególnej, wyróżniającej się na tle innych kategorii gramatycznych, a zarazem wyróżniającej grupę języków, dla których jest charakterystyczna. Mimo że praca jest poświęcona - zgodnie $\mathrm{z}$ informacją zawartą $\mathrm{w}$ tytule - aspektowi polskiego czasownika, jej Autor w wielu momentach przyjmuje perspektywę porównawczą, na przykład przywołując języki bezaspektowe czy zaznaczając podobieństwa i różnice w zakresie sposobów tworzenia odpowiedników aspektowych poszczególnych czasowników w różnych językach słowiańskich. Uwidaczniające się w niektórych częściach opracowania podejście komparatystyczne polega nie tylko na porównaniu niektórych elementów (np. formalnych wyznaczników czy semantyki) kategorii aspektu w języku polskim i innych językach słowiańskich. Realizuje się ono także poprzez odwołania do koncepcji i wyników badań dotyczących aspektu w innych językach, głównie słowiańskich - w tym na przykład do prac Jurija Masłowa, Siergieja Karcewskiego, czy Stephena M. Dickeya (m.in. Maslov 1959; Karcevski 1927; Dickey 2016) - oraz poprzez próby ustalenia, w jakim stopniu teorie dotyczące aspektu w innych językach można odnosić do aspektu w języku polskim.

Choć anonsowane w pierwszym rozdziale książki zagadnienia znajdują - zgodnie z zamysłem kompozycyjnym, o którym Autor pisze we wstępie - swoje właściwe rozwinięcie i pogłębioną analizę dopiero w rozdziałach kolejnych, to już od pierwszych stronic uwidacznia się główny rys tej pracy - nastawienie na opis semantycznych parametrów aspektu. Biorąc pod uwagę to, że wykładniki formalne aspektu (w języku polskim i innych językach słowiańskich) doczekały się już wielu szczegółowych opracowań, zogniskowanie uwagi na semantyce

* monika.szymanska@ijp.pan.pl, ORCID: oooo-0oo2-6708-2579 
opisywanej kategorii wydaje się istotną przesłanką do uznania Wykładów o aspekcie polskiego czasownika za pozycję nie tylko odpowiadającą na potrzebę kompleksowego ujęcia kategorii aspektu, ale także wnoszącą istotny wkład w rozwój badań nad kategorią czasownika w ogóle. Nie znaczy to, że formalna strona aspektu została w jakikolwiek sposób w tym opracowaniu zaniedbana, ale że jej opis został zintegrowany z opisem wymiaru semantycznego. W opisie zróżnicowania i uwarunkowań dystrybucyjnych morfologicznych wykładników aspektu wskazano, w jak znacznym stopniu są one zależne od semantyki czasowników, od ich przynależności do poszczególnych klas semantycznych (np. do klas czasowników telicznych, iteratywnych, ingresywnych czy skutkowych).

Podejmując temat aspektu czasownika, Autor nie mógł uniknąć odpowiedzi na zasadnicze pytanie towarzyszące językoznawczej refleksji nad tą kategorią niemal od samego początku. Pytanie to pada w podrozdziale zatytułowanym Aspekt między fleksją a słowotwórstwem, a brzmi następująco: „Czy związki między członami pary aspektowej trzeba analizować na płaszczyźnie odmiany, czy słowotwórstwa?” (s. 37). Od przywołania koncepcji aspektu reprezentujących pierwszy i drugi biegun tej opozycji oraz takich, które można sytuować gdzieś pomiędzy nimi - jak choćby koncepcję Wiktora Winogradowa (Vinogradov 1952), Autor przechodzi do stwierdzenia: „W tej książce będziemy traktować aspekt jako kategorię gramatyczną o wykładnikach słowotwórczych" (s. 40). Tę deklarację (dającą się z pozycji czytelnika uznać za sygnał dystansowania się od kategorycznego, jednoznacznego rozstrzygnięcia i sugerującą, że dotyczy ona tylko rozwiązania przyjmowanego na potrzeby tego konkretnego opracowania) Autor rozwija jednak dalej, określając aspekt jako „kategorię klasyfikującą formotwórczą, która posługuje się środkami słowotwórczymi, ale wpływa na zasięg paradygmatu fleksyjnego" (s. 41).

Wspomniane już wyżej ukierunkowanie na analizę semantycznych podstaw kategorii aspektu znalazło realizację $\mathrm{w}$ formie interesującego badania przedstawionego $\mathrm{w}$ podrozdziale Statystyka aspektu. Obejmowało ono analizę rozkładu form aspektowych w Wielkim słowniku angielsko-polskim PWN-Oxford (2003) oraz w Słowniku gramatycznym języka polskiego (SGJP) i wykazało, że pary aspektowe tworzy około 90\% polskich czasowników. Wynik ten został zinterpretowany jako potwierdzenie silnych uwarunkowań semantycznych kategorii aspektu - znacznie silniejszych niż na przykład w przypadku kategorii rodzaju rzeczownika. Badanie dowiodło bowiem, że poza opozycją motywowaną semantycznie pozostaje tylko $10 \%$ czasowników (tyle spośród nich nie tworzy par aspektowych) i aż 90\% rzeczowników (ponieważ tylko $10 \%$ wchodzi w opozycje rodzajowe oparte na kryterium płci).

Na metodzie kwantytatywnej opiera się również inna zaprezentowana w Wykładach analiza - badanie korpusowe rozkładu form aspektowych w tekście, mające na celu ustalenie profilów gramatycznych użycia czasowników dokonanych i niedokonanych. Techniki badań korpusowych zostały tu także wykorzystane do analizy kolokacji tych czasowników. Oprócz dość oczywistego (trzeba przyznać, że nawet w zupełności intuicyjnie przewidywalnego) wniosku o skłonności czasowników niedokonanych do kookurencji z okolicznikami trwania i powtarzalności, a czasowników dokonanych z okolicznikami momentalnymi analiza ta przynosi też ciekawsze wyniki - dotyczące korelacji między aspektem czasownika a dopełnieniem bliższym (obecnością lub elipsą tego dopełnienia, a także jego formą gramatyczną). 
Zaprezentowane w monografii badania statystyczne dotyczące kategorii aspektu nawiązują dość wyraźnie do nurtu badań podejmowanych na gruncie językoznawstwa kognitywnego (wykorzystującego na coraz szerszą skalę metody korpusowe), polegających na profilowaniu gramatycznym i uwzględniających frekwencję oraz dystrybucję form gramatycznych reprezentujących określone kategorie gramatyczne (por. np. Janda 2016; Kuznetsowa 2015).

Choć Autor zaznacza, że monografia odwołuje się do „klasycznego językoznawstwa strukturalnego" (s. 24), to jednak dają się w niej zauważyć elementy podejścia charakterystycznego dla szeroko rozumianego językoznawstwa kognitywnego. Notabene przytoczona deklaracja pojawia się w kontekście wykorzystania zaadaptowanego przez Autora na potrzeby jego opracowania pojęcia prototypu, a więc jednego z podstawowych pojęć typowych dla metodologii kognitywnej, od której - formułując przywołaną deklarację - Autor się dystansuje.

Specyfika kategorii aspektu wymaga, aby jej kompleksowe, monograficzne opracowanie uwzględniało nie tylko perspektywę porównawczą, ale również diachroniczną ${ }^{1}$. W Wykładach oba te podejścia dochodzą do głosu w wielu miejscach, a zbiegają się i szczególnie silnie zaznaczają w rozdziale poświęconym genezie i kształtowaniu się aspektu w polszczyźnie. Podobnie jak w rozważaniach dotyczących innych zagadnień związanych $\mathrm{z}$ aspektem także $\mathrm{w}$ analizie jego genezy oraz ewolucji w recenzowanej monografii zaznacza się ukierunkowanie na sferę semantyki, o czym świadczy choćby konkluzja podrozdziału Geneza aspektu podkreślająca szczególną rolę dwóch kategorii semantycznych: iteratywności - jako semantycznej podstawy niedokonaności - oraz teliczności, która jest podstawą dokonaności.

W tym samym rozdziale, przedstawiającym aspekt z punktu widzenia historycznojęzykowego, znalazło się również omówienie roli prefiksów czasownikowych w kształtowaniu się kategorii aspektu. Zostały one scharakteryzowane ze względu na wnoszone przez nie znaczenia dodatkowe, co wynika z przyjętego przez Autora stanowiska, że tzw. prefiksy czysto aspektowe (wbrew temu, co sugeruje stosowane przez niektórych językoznawców określenie „puste przedrostki aspektowe”) „nie są w istocie pozbawione znaczenia wspólnego danemu przedrostkowi w innych połączeniach” (s. 72).

Istotny punkt opracowania stanowi kwestia klasyfikacji akcjonalnej czasowników, czyli podziału ze względu na typy sytuacji, które są przez nie oznaczane i znajdują odzwierciedlenie w opozycji kategorialnej aspektu. Punkt ten został poprzedzony przeglądem sposobów definiowania sytuacji i zdarzenia z punktu widzenia logiki i filozofii. Następnie przedstawiono kilka różnych semantycznych klasyfikacji czasowników, w tym klasyfikację predykatów angielskich Zeno Vendlera (1957) oraz jej adaptacje powstałe na gruncie badań nad językami słowiańskimi, a wśród nich między innymi klasyfikację semantyczną czasowników polskich Romana Laskowskiego zawartą w GWJP-M (1984). Zapowiedź otwierająca rozdział Klasy akcjonalne: „W tym rozdziale podzielimy czasowniki, a właściwie predykaty, ze względu na klasy sytuacji, które mogą być przez nie oznaczane" (s. 90), nie pociąga za sobą propozycji jakiegoś zupełnie

1 Uzasadnienie dla poświęcenia szczególnej uwagi kwestii genezy aspektu zostało przez Autora sformułowane explicite: „Do zrozumienia polskiej i słowiańskiej opozycji aspektowej wiedza historycznojęzykowa jest potrzebna jeszcze bardziej niż do opisania kategorii liczby czy rodzaju" (s. 52). 
nowego podziału - wspomniana prezentacja istniejących już podziałów kończy się tylko informacją, że w książce przyjęto klasyfikację Vendlerowską, wzbogaconą o semelfaktywa.

Od kwestii zróżnicowania czasowników, będącego podstawą ich podziału na klasy akcjonalne, Autor przechodzi do problemu inwariantu dokonaności, który stanowi podstawę opozycji aspektowej i obejmuje całościowe ujęcie akcji, pojęciowe oddzielenia jej od innych stanów rzeczy i przedstawienie jako pojedynczego zdarzenia. Podkreśla w tym miejscu istotną rolę pojęcia granicy (końca zdarzenia i początku nowego stanu) jako jednego z podstawowych pojęć aspektologii. Następny rozdział poświęca szczegółowym znaczeniom aspektów dokonanego i niedokonanego, w tym znaczeniom aktualnotrwałym, duratywnym, wielokrotnym, potencjalnym, ogólnofaktycznym czy znaczeniom praesens historicum i praesens scenicum; w kolejnym natomiast pokazuje, w jaki sposób aspekt wpływa na funkcję poszczególnych form paradygmatu czasownika (nie tylko form osobowych, ale także bezokolicznika, bezosobnika czy imiesłowów) w konstruowaniu narracji. Podstawowa różnica między aspektami dokonanym a niedokonanym w tym obszarze polega - jak wykazano - na tym, że pierwszy wyznacza granice zdarzeń, podczas gdy drugi oznacza stany lub łańcuchy zdarzeń.

Odrębny rozdział poświęcono specyfice funkcjonowania aspektu w tekście prawnym. Wykazano w nim, że niejednoznaczność interpretacji gramatycznej może mieć wpływ na interpretację regulacji prawnych. Szczególnie interesująca wśród poruszonych w tym rozdziale problemów wydaje się kwestia znaczenia czasownika niedokonanego, które w kodeksie nie może być odczytywane jako znaczenie wielokrotne ${ }^{2}$. Po lekturze tego rozdziału nasuwa się pytanie, czy w opracowaniu dotyczącym aspektu - oprócz funkcjonowania kategorii aspektu w tekstach prawnych - nie należało także uwzględnić roli tej kategorii gramatycznej w innych typach tekstów i innych odmianach języka, na przykład w dyskursie naukowym czy w tekstach literackich. Roli aspektu w języku literatury pięknej dotyczy częściowo zawarta w rozdziale piątym analiza jego funkcji narracyjnych, poza tym w kilku miejscach Autor przywołuje przykłady twórczego podejścia do aspektu (np. w poezji Bolesława Leśmiana). To, że tak bardzo wyróżniono kwestię funkcjonowania aspektu w języku prawnym, w sposób naturalny rodzi jednak refleksję, że równie istotne byłoby prawdopodobnie także podkreślenie roli aspektu choćby w języku artystycznym, a być może również opisanie jej specyficznych realizacji w kategoriach figuratywności.

Sporo miejsca poświęcono w Wykładach kwestii ujmowania kategorii aspektu w leksykografii. Prześledzono - z różnym stopniem dokładności - sposoby odnotowywania aspektu czasownika i przedstawiania aspektowych par czasowników w słownikach ogólnych języka polskiego - od słownika Lindego poczynając, a na Wielkim słowniku języka polskiego PAN (wSJP PAN), kończąc. Temu ostatniemu postawiono zarzut, że opisuje aspekt „mniej więcej tak jak w Innym słowniku języka polskiego” (ISJP), czyli „według tradycyjnej zasady łączenia par sufiksalnych i rozdzielania prefiksalnych" (s. 262), podczas gdy jako słownik elektroniczny

2 Można to - oczywiście bardzo upraszczając - wyjaśnić, korzystając z cytowanego w recenzowanej książce przykładu zapisu: „Kto powoduje ciężki uszczerbek na zdrowiu [...] podlega karze pozbawienia wolności od roku do lat 10”, w którym znaczenie czasownika niedokonanego powodować nie może być interpretowane w ten sposób, że karze podlega tylko wielokrotne dokonywanie tego zabronionego czynu. 
dysponuje on technicznymi możliwościami rozdzielnego ujmowania wszystkich członów par aspektowych - prefiksalnych i sufiksalnych - w odrębnych hasłach. Ten zarzut okazuje się o tyle nietrafny, że według założeń „w WSJP PAN czasowniki tworzące pary aspektowe zawsze są opracowywane w dwóch odrębnych hasłach (zarówno typ prefiksalny: robić - zrobić, jak i typ: wykonać - wykonywać)" (Żmigrodzki 2018: 27). Pary te są połączone w słowniku systemem hiperłączy pozwalających odbiorcy przejść od jednego do drugiego członu.

Kończąc omówienie monografii, warto przywołać jeszcze przedstawiony w jej zakończeniu „algorytm użycia aspektu w polszczyźnie”. Podsumowuje on w sposób syntetyczny dociekania nad specyfiką aspektu jako kategorii gramatycznej silnie uwarunkowanej semantycznie dociekania, które przez swój wkład w rozwój (nie tylko) polskiej aspektologii niewątpliwie zasługują na uwagę i uznanie.

Bibliografia

Dickey S.M. 2016: The evolution of Slavic aspect, De Gruyter Mouton, Berlin.

GWJP-M: Gramatyka wspótczesnego języka polskiego. Morfologia, red. R. Grzegorczykowa, R. Laskowski, H. Wróbel, Państwowe Wydawnictwo Naukowe, Warszawa 1984.

ISJP: Inny słownik języka polskiego, red. M. Bańko, Wydawnictwo Naukowe PWN, Warszawa 2000.

Janda L.A. 2016: Linguistic profiles. A quantitative approach to theoretical questions, [w:] D. Szumska, K. Ozga (red.), Âzyk i metod, t. 3, Wydawnictwo Uniwersytetu Jagiellońskiego, Kraków, s. 127-146.

Karcevski S. 1927: Système du verbe russe. Essai de linguistique synchronique, Legiografie, Prague.

Kuznetsova J. 2015: Linguistic profiles. Going from form to meaning via statistics, De Gruyter Mouton, Berlin-Boston.

Maslov J.S. 1959: Glagol'nyj vid v sovremennom bolgarskom literaturnom âzyke, [w:] Voprosy grammatiki bolgarskogo literaturnogo âzyka, Izdatel'stwo Akademii Nauk SssR, Moskva, s. 157-312.

SGJP: Słownik gramatyczny języka polskiego, red. Z. Saloni, W. Gruszczyński, M. Woliński, R. Wołosz (online: http://www. sgjp.pl).

Vendler Z. 1957: Verbs and times, „The Philosophical Review”, vol. 66(2), s. 143-160.

Vinogradov V.V. 1952: Slovoobrazovanie v ego otnošenii $k$ grammatike i leksikologii (Na materiale russkogo $i$ rodstvennyh âzykov), [w:] G.F. Aleksandrov i in. (red.), Voprosy teorii i istorii âzyka v svete trudov I.V. Stalina po âzykoznaniû, Izdatel'stwo Akademii Nauk SssR, Moskva, s. 99-152.

Wielki słownik angielsko-polski PWN-Oxford, red. J. Linde-Usiekniewicz, Warszawa 2002.

WSJP PAN: Wielki słownik języka polskiego PAN, red. P. Żmigrodzki (online: http://www.wsjp.pl, dostęp 20 września 2021). Żmigrodzki P. 2018: Makro- i mikrostruktura słownika. Sposób prezentacji materiału, [w:] P. Żmigrodzki, M. Bańko, B. Batko-Tokarz, J. Bobrowski, A. Czelakowska, M. Grochowski, R. Przybylska, J. Waniakowa, K. Węgrzynek (red.), Wielki słownik języka polskiego PAN. Geneza, koncepcja, zasady opracowania, Instytut Języka Polskiego Polskiej Akademii Nauk - Libron, Kraków. 